\title{
A Voice Opposition without Voice Morphology
}

\author{
Mark Donohue \\ National University of Singapore
}

\section{Voice systems in Austronesian languages}

The symmetrical voice systems of the western Austronesian languages are well known; Schachter $(1976,1977)$ provides a succinct summary of the issues, and numerous works before and since have argued variously for passive and ergative (and other) interpretations of the data. It is widely supposed that the Central-eastern Malayo-Polynesian languages lack voice oppositions: such mechanisms are widely reported to be absent in Papuan languages, and are generally assumed to be absent from the Austronesian languages of the area. ${ }^{1}$ The complex voice systems of the western Austronesian languages are present in only relic form (see Wouk and Ross 2002), and the Oceanic passives (*taand ${ }^{*}$ ma-) are only weakly attested (Donohue 2004).

Another pattern of voice marking is found in many eastern Indonesian and western Melanesian languages, separated from the more well-recognised western languages that have overt, dedicated voice marking morphology, and separate from the well-described passive and passive-like morphemes (*ta or *ma) that are found in the Pacific. Tukang Besi, the south-easternmost Western Malayo-Polynesian language, is one such language. Like other Muna-Buton languages, Tukang Besi has pronominal agreement on the verb to index the core arguments of the clause. The morphological template for the pronominal inflection on the verb is shown in (1) (the same template holds for other pronominal voice languages): ${ }^{2}$

Morphological template for verbal inflection

Verb $=$ Agreement $\mathrm{S}, \mathrm{A}-$ Verb root $-($ Agreement $\mathrm{P})$

While agreement for the S,A argument is obligatory agreement for the $\mathrm{P}$ is not. The conditions that determine its appearance are complex, and shall be mentioned here only as far as they concern the presentation of this form of variation as part of the grammatical voice system. The bulk of this paper deals with an analysis of the voice system of Tukang Besi, which, has both a complex verbal agreement system as well as the last fully developed (and obligatory) case marking system among Austronesian languages with an increasingly head-marking trend to the east (case marking of core constituents only becomes functional again in Vanuatu and the Solomons, and is welldeveloped in Polynesia). For that reason, as well as personal acquaintance with the language, it is a sensible starting point.

\section{Tukang Besi voice: multifunctional morphology}

The voice system in Tukang Besi is marked only by variation in the verbal agreement system, as described in (1), not by the presence of any distinct voice-marking morphology. In Tukang Besi agreement for the S,A argument is obligatory, while agreement for a $\mathrm{P}$ is by enclitic, and is for most lexemes 
generally optional. When it occurs there are further morphosyntactic changes in the sentence, affecting word order possibilities, case marking coding, and most relevantly grammatical function assignment. What does NOT change is the identity of the argument indexed by the agreement prefix, indicating that the voice system is not one that involves demotion of one argument in order to promote the other, such as familiar passive or antipassive systcms from languages like English or the Mayan languages, but is more similar to the Austronesian voice systems from the west, as might be expected. This also indicates that when the voice changes the categories that determine which agreement markers are used to index an argument do not, showing that 'subject' and 'object' are not appropriate labels to apply to the prefixes and enclitics.

\subsection{The voice system: basics and argumentation}

In both voices the verb is prefixed to index the values of the S or A, and in the non-active voice there is an enclitic which bears the pronominal features of the $\mathrm{P}$. When the $\mathrm{P}$ is indexed no fixed order holds between the DPs representing the postverbal $\mathrm{A}$ and $\mathrm{P}$ arguments, while a clause that lacks $\mathrm{P}$ agreement is only grammatical when the $\mathrm{P}$ precedes the $\mathrm{A}$, in a VP constituent. ${ }^{3}$ These facts are summarised in table 1, and illustrated in (2) - (6).

$$
\begin{array}{lllll}
K u \text {-'ita }=\text { 'e } & (t e & i a k u) & n a & \text { ana. } \\
\text { 1SG-see=3P CORE } & 1 \mathrm{SG} & \text { CORE } & \text { child } \\
\text { 'I saw the child.' } & & &
\end{array}
$$

(3) Ku'ita'e na ana te iaku.

(4) Ku-'ita te ana (naiaku).

1SG-see CORE mother NOM 1SG 'I saw a child.'

(5) * ku'ita na iaku te ana.

(6) No-waliako=mo na anai kampo. 3R-return=PF NOM child OBL village 'The child returned to the village.'

Table 1. Agreement, word order and case marking in Tukang Besi

\begin{tabular}{llllll}
\hline Clause type & \multicolumn{2}{c}{ variant } & Agreement & word order & \multicolumn{2}{c}{ case marking } \\
& & & & $\mathrm{A}$ & $\mathrm{S}$ \\
\hline Bivalent & P indexed on $\mathrm{V}$ & $\mathrm{A}-\mathrm{V}=\mathrm{P}$ & $\mathrm{V} \mathrm{A} \mathrm{P}(\sim \mathrm{VPA})$ & $t e$ & $n a$ \\
& P not indexed on V & $\mathrm{A}-\mathrm{V}$ & $\mathrm{V} \mathrm{P} \mathrm{A}$ & $n a$ & $t e$ \\
Monovalent & & $\mathrm{S}-\mathrm{V}$ & $\mathrm{V} \mathrm{S}$ & \multicolumn{2}{c}{$n a$} \\
\hline
\end{tabular}

The relevant testable phrase-structure configuration of the clause, with no preverbal elements, is shown in (7), which also shows the positional possibilities for adjunct material of different classes. Adverbs appear within the VP, left- or right- adjoined to any element. Locative adjuncts appear following the VP, while time adjuncts are constrained to appear following the S or A of the clause, that is, right of the IP. Table 2 shows the pronominal forms. ${ }^{4}$ The free pronouns are listed to show the degrees of relative grammaticalisation between them and the bound verbal forms, the P clitics clearly being a more recent grammaticalisation than the prefixes. 
(7)

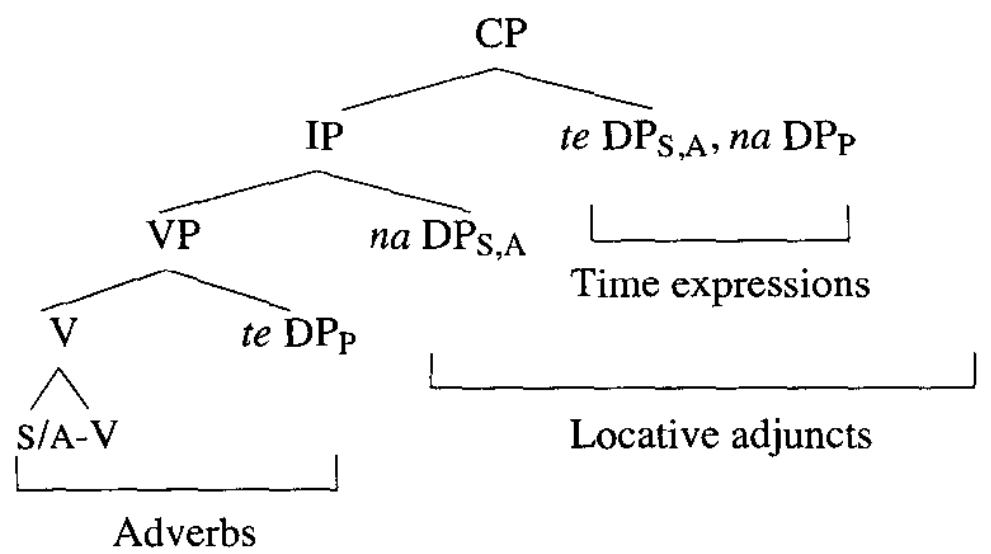

Table 2. Pronominal forms in Tukang Besi

\begin{tabular}{|c|c|c|c|c|c|}
\hline \multirow{2}{*}{$\begin{array}{l}\text { Position: } \\
\text { Role: } \\
\text { (mood): }\end{array}$} & \multicolumn{2}{|c|}{$\begin{array}{c}\text { Pre-root } \\
\text { S,A }\end{array}$} & \multirow[t]{2}{*}{$\begin{array}{c}\text { Post-root } \\
\text { P }\end{array}$} & \multirow{2}{*}{\begin{tabular}{l}
\multicolumn{1}{c}{ Post-root } \\
nominal POSS'R, \\
subordinate A, S, P
\end{tabular}} & \multirow[t]{2}{*}{$\begin{array}{l}\text { Independent } \\
\text { (any) }\end{array}$} \\
\hline & realis & irrealis & & & \\
\hline $1 \mathrm{SG}$ & $k u-$ & $k u-$ & $=a k u$ & $=s u$ & iaku \\
\hline $2 \mathrm{SG}$ & 'u-/nu- & ko- & $=k o$ & $={ }^{\prime} u$ & $i k o^{\prime} o$ \\
\hline $3 \mathrm{SG}$ & no- $/ o-$ & $n a-/ a-$ & $={ }^{\prime} e$ & $=n o$ & $i a$ \\
\hline 1PA & ko- & $k a-$ & $=k a m i$ & $=$ nto & ikami \\
\hline $1 \mathrm{PL}$ & to- & $t a-$ & $=k i t a$ & $=m a m i$ & ikita \\
\hline 2PL & $i-$ & $k i-$ & $=k o m i u$ & $=m i u$ & ikomiu \\
\hline 3PL & no- / o- & $n a-/ a-$ & $=^{\prime} e$ & $=n o$ & amai \\
\hline
\end{tabular}

We shall return to the restrictions on the appearance of free and bound pronouns in more detail in 2.3 .

\subsection{The syntax of pronominal voice in Tukang Besi}

While the use of S,A prefixes is obligatory, the use of P clitics is not. This has been seen in (2) and (4). The use of P-coding clitics on the verb has consequences for the assignment of properties associated with grammatical functions. This has been described elsewhere (Donohue 1999a, 1999b, 2002), but the essential properties are:

- the restriction of floated quantifiers;

- conjunction reduction;

- eligibility to appear as the head of an internal relative clause;

- external possession (possessor raising, possessor ascension).

Floated quantifiers can only refer to a nominative argument; this will be the single argument of a monovalent clause, and for a bivalent clause it will be the $\mathrm{P}$, if there are $\mathrm{P}$-coding clitics on the verb, or the $\mathrm{A}$ if there are not.

Floated quantifier referring to an A

[QUANT Saba'ane] no-lemba te kaluku [na amai].

all 3R-carry CORE coconut NOM 3PL

'All of them carried coconuts.'

* 'They carried all of the coconuts.' 
Floated quantifier referring to a $\mathrm{P}$

\begin{tabular}{|c|c|c|c|c|c|}
\hline [QUANT Saba'ane] & $\begin{array}{l}\text { no-lemba='e } \\
3 \mathrm{R} \text {-carry }=3 \mathrm{P}\end{array}$ & $\begin{array}{l}{[n a} \\
\text { NOM }\end{array}$ & $\begin{array}{l}\text { kaluku] } \\
\text { coconut }\end{array}$ & $\begin{array}{l}\text { te } \\
\text { CORE }\end{array}$ & $\begin{array}{l}\text { amai. } \\
\text { 3PL }\end{array}$ \\
\hline
\end{tabular}

Conjunction reduction preferentially applies between nominative arguments in adjacent clauses. A textual example is presented in section 3, but the following sentences illustrate the principle. In both sentences the preferred controller for the third person argument of the monovalent clause nowaliakomo di kampo is the nominative argument of the following clause, even if there are no overt nominals in the second clause.

Coreference between $\mathrm{S}$ and $\mathrm{A}$, both nominative

No-waliako $=m o$ di kampo, maka no-'ita te ana.

3R-return=PF OBL village and then 3R-see CORE child

' $\varnothing_{\mathrm{i}}$ returned home, and then $\emptyset_{\mathrm{i}}$ saw a child $\mathrm{j}$.'

Coreference between $\mathrm{S}$ and $\mathrm{P}$, both nominative

(11) No-waliako=mo di kampo, maka no-'ita='e (te ana). $3 \mathrm{R}-$ return $=\mathrm{PF} \quad \mathrm{OBL}$ village and then $3 \mathrm{R}-\mathrm{see}=3 \mathrm{P}$ CORE child ' $\emptyset_{\mathrm{i}}$ returned home, and then (a child $\left./ \varnothing\right)_{\mathrm{j}}$ saw $\emptyset_{\mathrm{i}}$.'

Internal relative clauses show complex restrictions; only an absolutive argument (an $\mathrm{S}$ or a $\mathrm{P}$ ) may appear as head, and moreover that argument must be nominative. This is trivial for an $S$, but for the $P$ we can see that this restriction forces $\mathrm{P}$-voice.

Internal relative clauses referring to a nominative $\mathrm{P}$
No-waliako=mo [RC to-siasia $=$ ' $e \quad$ na mia
3R-return=PF 1PL.R-beat.up=3P NOM person OBL previous
'The person we beat up before has gone home.'
Internal relative clauses referring to a non-nominative $\mathrm{P}$
(13) * no-waliako=mo [RC to-siasia te mia $i$ aba]
3R-return=PF 1PL.R-beat.up NOM person OBL previous
'The person we beat up before has gone home.'

External possession is restricted to Ps and patient-like Ss (unaccusative subjects) (Donohue 1999b), in non-active, if bivalent, thus establishing a requirement that the external possessor must be nominative.

External possession with a nominative $\mathrm{P}$
No-siasia $=k o=m o \quad$ na ikaka=' $u$.
3R-beat.up=2SG.P $=$ PF $\quad$ NOM eSi=2SG.GEN
'They beat up your big brother.'
External possession with a non-nominative $\mathrm{P}$
(15) * no-siasia=moq (na / te) iko'o (na / te) ikaka='u
3R-beat.up=PF NOM/CORE 2SG NOM/CORE eSi=2SG.GEN
'They beat up your big brother.'

Clearly there are far-reaching grammatical consequences to the clause, in terms of constructional restrictions, that correlate with the choice of the verb 
appearing with P-enclitics or not. We have, thus, established a voice system in which the identity of the grammatical subject changes (see Falk 2000 for arguments on why these constructions are suitable to establish grammatical subject status, and are not simply ones that identify an argument structure position). Evidence that the $\mathrm{A}$ is a core argument in both the $\mathrm{P}$-agreement and the non-P-agreement constructions is easy to find. The A participant:

- remains indexed on the verb by invariant prefix regardless of voice, as seen in the invariant use of $k u$ - to show agreement with the S,A in both (2) and (4);

This shows that the determination of prefixal verbal agreement is based on lexically-assigned argument structure relationships, and not the voice-sensitive grammatical functions.

- is marked with a core case, na 'nominative' or te 'generic core argument', depending on the voice (again, see examples (2) and (4) above);

Neither the general oblique $i$, nor any of the more specialised oblique prepositions, may be used to mark an A.

- is available to bind a reflexive regardless of its status with respect to the voice system (cf. Arka and Manning 1998).

The reflexive facts can be seen in the following two sentences (Donohue 1999a: 418), in which the marking or absence of marking for the $\mathrm{P}$ on the verb does not affect the ability of the A to bind a reflexive.

O-pepe='e na karama=no te ana.
3R-hit=3P NOM self=3GEN CORE child
'The child hit her/himelf.'
O-pepe te karama=no na ana.
3R-hit CORE self=3GEN NOM child
'The child hit her/himelf.'

A sentence with a reflexive agent, analogous to the English "He was promoted by himself', is ungrammatical in Tukang Besi. This is most apparent with a non-third person $\mathrm{S}, \mathrm{A}$. (18) has a verb with prefixal agreement for the $\mathrm{S}, \mathrm{A}$, and (19) additionally shows agreement with the reflexive P, just as in (2) and (4). (20) is ungrammatical because it assigns the reflexive karama' $u$ to the A position, grammatical in English since it is an oblique in the passive construction. The ungrammaticality of sentences such as (20) shows that the Pvoice construction cannot be interpreted as a passive with an oblique $\mathrm{A}$. This leads us to assume that the voice system involves an effective reversal of the assignment of grammatical functions to the two arguments of the bivalent verb. (Examining three or more place predicates shows that the voice system deals only with the highest two arguments for the purposes of voice assignment. Further arguments (such as the theme of a verb like $h u^{\prime} u$ 'give') are syntactically inert 'second objects'.)

$\begin{array}{ccc}\text { 'U-tulumi } & \boldsymbol{t} \boldsymbol{e} & \text { karama=' } \boldsymbol{u} . \\ \text { 2SG.R-help } & \text { CORE } & \text { self=2SG.GEN } \\ \text { 'You helped yourself.' } & \end{array}$


' $U$-tulumi $=$ ' $e \quad$ na $\quad$ karama $=$ ' $u$.

2SG.R-help=3P NOM self=2SG.GEN

(20) * no-tulumi $=$ ko te karama $=$ ' $u$

3R-help=2SG.P CORE self $=2$ SG.GEN

'You were helped by yourself.'

This voice system cannot be characterised as active/passive, or active/antipassive: in both of the bivalent coding options there are two core arguments. The voice system then represents more closely those of the Philippine languages, or the inverse systems of some Cariban or Algonquian languages (though not all; see Dahlstrom 1991). This can be shows with the following crude mapping of argument structure positions to grammatical functions in Tukang Besi (shown using the conventions from Alsina 1996) (Arguments against an ergative-with-antipassive analysis are given in Donohue 1999a: 160-166).

A-structure / GF-mapping for the pronominal voice alteration
a. No enclitics

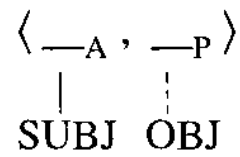
b. P enclitics

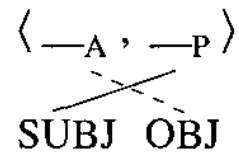

An approach such as that advocated in Sells (2001), in which the P is raised in a clause with $P$ clitics on the verb, would more formally capture the generalisations illustrated here. Note that, in Tukang Besi, rather than being covert the pronominal incorporation on the verb posited by Sells is overt, in the form of the $\mathrm{P}$ agreement clitics.

\subsection{Interactions with person}

It is not ungrammatical for an indexed pronominal to also be represented by a free pronoun in the same clause; this is extremely rare, but is attested in texts. Such constructions are usually associated with pragmatically marked information, and so are judged as being more natural if the case-marked pronoun appears preverbally, as in (23) and the textual (25).

$$
\begin{aligned}
& \text { No-'ita=aku te ana (\#!na iaku). } \\
& \text { 3R-see=1SG.P CORE child NOM 1SG } \\
& \text { 'The child saw me.' } \\
& \text { Te iaku no-ita=aku te ana. } \\
& \text { CORE 1SG 3R-see=1SG.P CORE child } \\
& \text { 'The child saw me.' } \\
& \text { \# To-waliako=mo } i \quad \text { kampo na ikita. } \\
& \text { 1PL.R-return=PF OBL village NOM 1PL } \\
& \text {...te iaku habuntu (')u-hu'u=aku te kuli=no... } \\
& \text { CORE 1SG in.fact 2SG.R-give=1SG.P CORE skin=3GEN } \\
& \text { '... in fact you've just given me the peel (of the bananas) ...' }
\end{aligned}
$$

Sentences such as (26), while consistently judged to be grammatical possible, are at best marginally felicitous, and are not part of any corpus of naturally-occurring speech. This implies a constraint requiring local person Ps to be the subject of their clause; morphologically, local persons should be 
marked on the verb. This does not apply to all local person, regardless of syntactic role; (27) shows an instance of a non-nominative local person A.

(26) */\# no-'ita te iaku na ana

3R-see CORE 1SG NOM child

'The child saw me.'

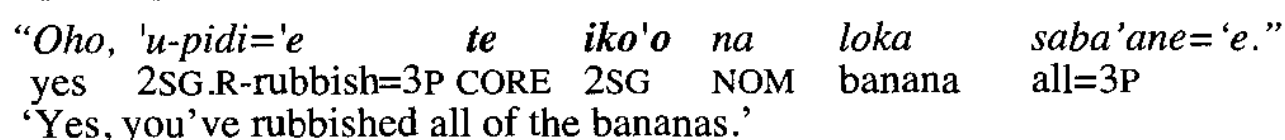

\subsection{Grammatical voice, not (just) pragmatic topic}

Given what is known about the evolution of agreement systems in language (for instance, Givón 1976), we might ask whether the construction with Pclitics involves a change in the pragmatic function status of the $\mathrm{P}$, but not the grammatical function status. This is a position that would be hard to sustain given the data on clause-internal constructions presented in the previous section, detailing the syntactic correlates of P-agreement, and the interaction with the person hierarchy.

Further evidence against a topic analysis involves the regular attestation of pre-verbal topics. Expanding the structure seen in (7), we might describe a monoclausal sentence in Tukang Besi as follows (after Donohue 1999: 80xxx). This accords well with what is described for other Austronesian languages.

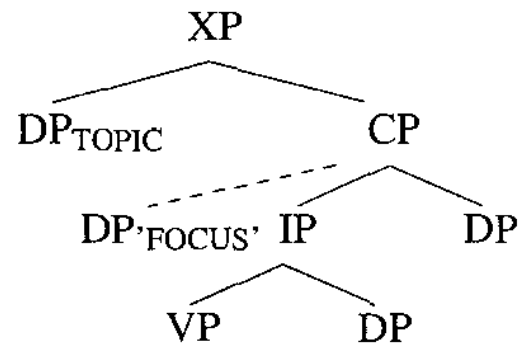

Examples of these structures can be found in the following textual extracts. The first shows that a 'true' topic, in preverbal position, need not have any grammatical connection with the arguments of the clause at all. In (29), in which two characters discuss the yield of a banana tree, the topic of the sentence, te iaku, is not the subject of the predicate. The textual extracts shown in (30) and (31) demonstrate that when a topic does serve as a term in the clause it is possible for it to be realised in the topic position alone, as in (30), or in both the preclausal topic position and overtly in the normal IP-internal position.

TOPIC

$\begin{array}{clll}\text { "E iaku iso no-ha'a na iso! } \\ \text { CORE 1SG yon } & \text { 3R-why NOM yon } \\ \text { No-'ido sa-ro'o, } & \text { o-mate } & \text { sa-ro'o." } \\ \text { 3R-live 1-leaf } & \text { 3R-die } & \text { 1-leaf }\end{array}$

'And me, it's just like that (ie., nothing at all). One leaf lives, and one leaf dies (ie., it's not doing too well).' 
TOPIC

...te iaku ku-[m]e-mbula te hu'u=no...

CORE 1SG 1SG-VRB.SI-plant CORE trunk=3GEN 'I will plant the trunk.'

TOPIC
Po'oli te ia iso no='eka=mo
finish CORE 3SG that 3R-ascend=PF
na La bela kape'ingkape'i kua wunua-no.
NOM Mr dear Fool al AL house=3GEN
'And then he, The Fool, went (back) up to his house.'

On the other hand, it remains true that nominative encoding is not compatible with pragmatically focussed question words; questions can be formed of and $\mathrm{A}$ or a $\mathrm{P}$ only if it is non-nominatively coded, or in a cleft; an S may only be questioned in a cleft.

$$
\begin{aligned}
& \text { 'U-ala te paira? } \\
& \text { 2SG.R-fetch CORE what } \\
& \text { 'What did you fetch?' } \\
& \text { No-ala= 'e te emai? } \\
& \text { 3R-fetch=3P CORE who } \\
& \text { 'Who fetched it?' }
\end{aligned}
$$

$$
\begin{aligned}
& \text { Te emai na } \text { [m]aliako? } \\
& \text { CORE who NOM return.SI } \\
& \text { 'Who returned?' }
\end{aligned}
$$

(33) * ' $u$-ala ='e na paira?

2SG.R-fetch $=3 \mathrm{P}$

(35) * no-ala na emai? 2SG.R-fetch

(37) * no-waliako na emai? 2SG.R-fetch

(38) Te paira na ni-ala=' $u$ ?

CORE what NOM PP-fetch=2SG.GEN

'What did you fetch?'
Te
emai na
[um]ala te
loka?
CORE what NOM fetch.SI
'Who fetched the banana(s)?'

This is not completely surprising, given the well-known correlations between the relative topicality of an A and a P and the choice of voice. This is summarised in table 3 .

Table 3. Topicality and voice choice

\begin{tabular}{ccc}
\hline Relative topicality of $\mathrm{A}$ and $\mathrm{P}$ & Preferred voice & Subject $=$ \\
\hline $\mathrm{A} \gg \mathrm{P}$ & antipassive & $\mathrm{A}$ \\
$\mathrm{A}>\mathrm{P}$ & active & $\mathrm{A}$ \\
$\mathrm{A}<\mathrm{P}$ & inverse & $\mathrm{P}$ \\
$\mathrm{A} \ll \mathrm{P}$ & passive & $\mathrm{P}$ \\
\hline
\end{tabular}

(Rarely are more than three of these voices instantiated for any one language. See Payne (1994), or Sells (2001) for the use of these labels as a combined voice+pragmatic function descriptors.)

There are, nonetheless, good reasons to consider the alternations to represent a voice system, and not simply an artefact of topicalisation (such as has been demonstrated for, amongst others, Chichewa - see section 3 ). The evidence involves the syntactic tests shown in 2.2 , and the semantic correlates described in the following section. 


\subsection{Semantic correlates of the pronominal voice system}

Other reasons for assuming that the pronominal voice system is a real voice system, and not simply an extended topicalisation phenomenon, become apparent when we examine the necessary semantic correlates of the voice choice made with this paradigm. In addition to the change in status of the grammatical functions, other effects associated with the use of P-clitics when there is an alternation include the following specification of the $\mathrm{P}$ argument:

- greater specificity or definiteness associated with the P;

- more referential or retrievable $P$.

The contrast between the following clauses shows the instantiation of these semantic parameters.

$$
\begin{aligned}
& \text { Ku-ala te loka. } \\
& \text { 1SG-fetch CORE banana } \\
& \text { 'I fetch some/a banana(s).' } \\
& \text { (irrealis, indefinite, nonspecific) }
\end{aligned}
$$

$$
\begin{aligned}
& \text { Ku-ala='e na loka. } \\
& \text { 1SG-fetch=3P NOM banana } \\
& \text { 'I fetched the banana(s).' } \\
& \text { (perfective, specific) }
\end{aligned}
$$

The fact that local persons are almost invariably marked on the verb, including when they have the role of the $P$ in a clause (see section 2.3) also matches what is known about correlations between animacy and voice choice/subject selection.

There are also correlations between aspectual interpretation and the choice of pronominal voice, something that we would not expect to find with a system that simply marked incorporate pronominal status and relative topicality. A P-voice clause is more telic/punctual/realis that an otherwise equivalent clause in active voice. Relative clauses with an -um-infixed verb (necessarily with an $\mathrm{S}$ or $\mathrm{A}$ as head), in which the normal perfective clitic $=m o$ cannot be used, use P-voice as one way to indicate a perfective aspect.

The telicity parameter has been illustrated in (40) and (41). This contrast in relative clauses can be seen in (42) and (43) (which, with (44), also demonstrate the continued function of the older Austronesian voice

\begin{tabular}{|c|c|c|c|c|}
\hline$(42)$ & $\begin{array}{l}\text { Te wowine } \\
\text { CORE woman } \\
\text { 'the woman wh }\end{array}$ & 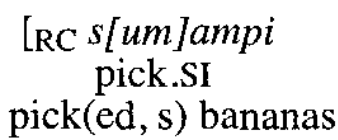 & $\begin{array}{ll}\text { te } & \text { lo } \\
\text { CORE } & \mathrm{b}\end{array}$ & $\begin{array}{l}k a] \\
\text { anana }\end{array}$ \\
\hline (43) & $\begin{array}{l}\text { Te wowine } \\
\text { CORE woman } \\
\text { 'the woman wh }\end{array}$ & $\begin{array}{c}\text { [RC } s[\text { um ]ampi=' } e \\
\text { pick.SI=3P } \\
\text { has picked the bana }\end{array}$ & $\begin{array}{c}n a \\
\text { NOM } \\
\text { ana(s) }\end{array}$ & $\begin{array}{l}\text { loka ] } \\
\text { banana }\end{array}$ \\
\hline (44) & $\begin{array}{l}\text { Te loka } \\
\text { CORE banana }\end{array}$ & $\begin{array}{ll}n i \text {-sampi } & n u \\
\text { PP-pick } & \text { GEN }\end{array}$ & $\begin{array}{l}\text { wowine ] } \\
\text { woman }\end{array}$ & \\
\hline
\end{tabular}
morphology - um- 'actor voice' and -in- 'PV' in subordinate clause, and show that in Tukang Besi they have become disassociated from the determination of grammatical functions).by a verb infixed with -um-; independently, the $\mathrm{P}$ clitics may be used to indicate a nominative $P$ in the relative clause, and a level of perfectivity not otherwise associated with this construction. Interestingly, relative clauses are one of the few cases in which local person Ps do not have to be coded on the verb, though that is still the preferred option. 
All of the semantic correlates illustrated here are factors that Hopper and Thompson associate with higher transitivity, and all are also variables commonly associated with the alternations of a voice system: voices that assign high grammatical status to the $\mathrm{P}$ of a clause are more likely to appear in past or perfective clauses, and to refer to more specific referents. Again, the agreement alternation in Tukang Besi functions semantically as a voice system can be expected to function.

\section{The genesis of a pronominal voice system}

While I have argued that the P-voice in Tukang Besi is not (simply) a case of a clause reflecting incorporated pronominal material and a topical $\mathrm{P}$ argument, there are striking similarities with such phenomena as reported in, for instance, Chichewa (Bresnan and Mchombo 1987). In both languages a P DP in a clause with P-coding agreement is outside the VP, while a P DP in a clause without agreement is inside the VP. We shall propose formal representation of the structure of clauses with and without $P$ agreement on the verb in (99) - (99).

Having two transitive verb forms differentiated by the presence or absence of P-agreement is not limited to Tukang Besi. Georgopoulos (1985, 1998) discusses similar correlations of 'object agreement' in Palauan, as does Kissock (2003) on Rotuman, and there is evidence that other languages of Melanesia also show pronominal voice alternations (section 4). In all cases these are languages that no longer display the original Austronesian voice morphology in its original function.

The historical loss and development of Austronesian voice morphology is summarised in (45), with considerable simplification.

\begin{tabular}{lllll} 
& \multicolumn{2}{c}{ Main Clause } & \multicolumn{2}{l}{ Subordinate clause } \\
& S,A subject & P subject & S,A subject & P subject \\
PAN & V-um- & V-in- & V-um- & V-in- \\
(Celebic) & V-um- & S,A-V & V-um- & V-in- \\
P M-B & S,A-V & S,A-V-P & V-um- & V-in-
\end{tabular}

The Tukang Besi system reflects the proto-Muna Buton system; we have seen the alternation in the main clause correlating with the presence or absence of P enclitics; the subordinate clause morphology has been seen in (36) and (38) - (39), as well as in (42) - (44). By comparison in Tagalog the original Austronesian voice morphology (Ross 2002) is used in a voice function in both main clause and subordinate clause positions.

$$
\begin{aligned}
& \text { P[um]unta ang bata sa pulo. } \\
& \text { examine.AV NOM child DAT island } \\
& \text { 'The child went to the island.' }
\end{aligned}
$$

S[um]uri ng kaibigan niya
examine.AV GEN friend ang bata.
'The child examined her/his friend.'

$\begin{array}{lllll}\text { Slinjuri } \quad \text { ng bata ang } & \text { kaibigan } & \text { niya. } \\ \text { examine.PV GEN child NOM } & \text { friend } & \text { 3SG.GEN } \\ \text { 'A child examined her/his friend.' } & & \end{array}$


We can see that there are good reasons to consider that the morphological alternation associated with the presence or absence of $\mathrm{P}$ clitics has replaced, in main clauses, the encoding of the voice by means of the infixes. The use of this voice alternation in discourse has been hinted at in 2.2 can be illustrated with a real textual example in (49). Here we can see that the preferred target of a clause-chaining construction is the subject of that clause, and the voice in that clause is selected to guarantee such coreference.

$$
\begin{aligned}
& \text { Ara ku-[m]o-busu na-t[um]alo=aku, kene te } \\
& \text { if 1SG-REC.SI-forward.fist 3I-win.SI=1SG.P and CORE } \\
& \text { ia no-pande di lola-'a, jari labi ku-akala='e. } \\
& \text { 3SG 3R-clever OBL fly-NL so better 1SG-trick=3P } \\
& \text { 'If } I_{i} \text { want to fight he }{ }_{j} \text { 'll beat } m_{i} \text {, and he } j \text { 's good at flying, so } \\
& \text { it'd be better if } I_{i} \text { tricked him }{ }_{j} \text {.' (Reiger \& Aap: 24) }
\end{aligned}
$$

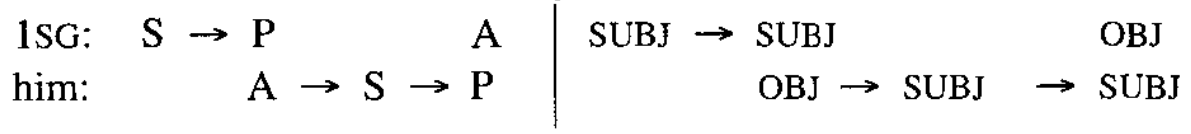

In (50) we have an alternative version of the same passage from the story, in which the syntactic roles of the participants are the same, but in which the grammatical function status of those arguments has been changed to deny the SUBJ $\rightarrow$ SUBJ preference in coreference. This retelling is uniformly judged to be much less felicitous than the original in (49).

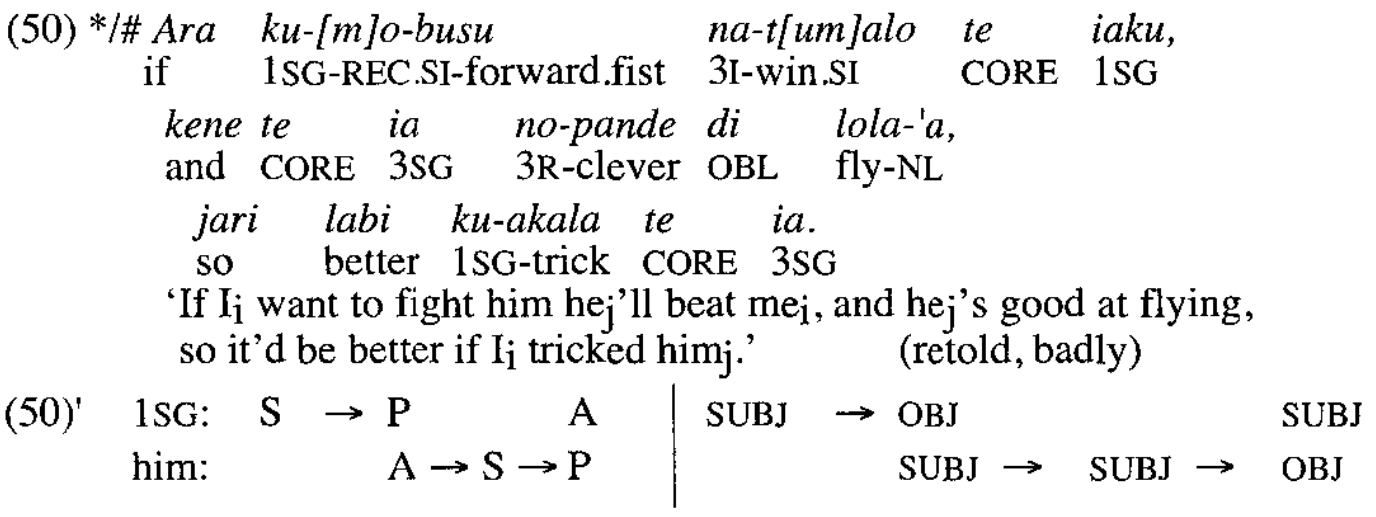

Following Bresnan and Mchombo (1987) I assume that the difference between clauses with $\mathrm{P}$ agreement on the verb and those without, in Chichewa, can be modelled as in (51) and (52). In (51) we see the DP representing the $P$ internal to the VP external to the VP, since it is already present in the VP in the form of the object agreement prefix on the verb. Furthermore, as described in Bresnan and Mchombo, there are positional freedoms associated with the $\mathrm{P}$ in this clause that are not found in a clause in which the verb lacks agreement for the $\mathrm{P}$. In a clause with no $\mathrm{P}$ clitics, the DP representing the $\mathrm{P}$ must appear inside the VP, and is not eligible for any special positional privileges. This is shown in (52). 
(51) Chichewa: Clause with P marking, enclitic interpreted as an anaphoric pronoun, nominal $\mathrm{P}$ topical and VP-external

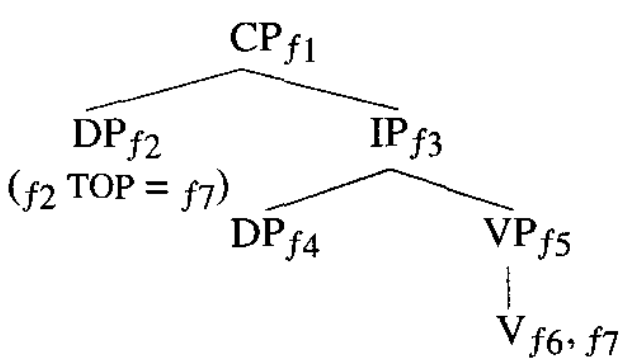

$$
f_{1}:\left[\begin{array}{ll}
f_{2}: \text { TOP }=f_{7}: & {[\text { PRED }=' \ldots ']} \\
f_{6}: \text { PRED } & \langle\ldots, \ldots\rangle \\
f_{2}:(\mathrm{A}) & {\left[\begin{array}{l}
\text { PRED }= \\
\text { PERS }=\alpha \\
\text { NUM }=\beta
\end{array}\right]} \\
f_{7}:(\mathrm{P}) & {\left[\begin{array}{l}
\text { PRED }= \\
\text { PERS }=\gamma \\
\text { NUM }=\delta
\end{array}\right]}
\end{array}\right]
$$$$
\begin{aligned}
& \left(f_{4} \text { A PERS }\right)=\alpha \\
& \left(f_{4} \text { A NUM }\right)=\beta
\end{aligned}
$$$$
\left(f_{2} \text { P PERS }\right)=\gamma
$$$$
\left(f_{2} \mathrm{P} \text { NUM }\right)=\delta
$$

(52) Chichewa: Clause without P-enclitic, nominal P fills argument position, VP-internal

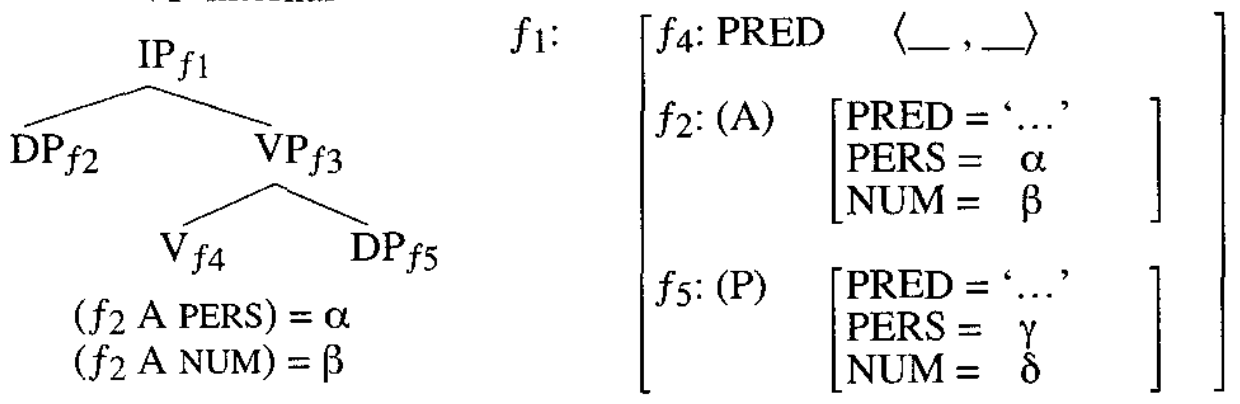

A typical model of the constituent structure and functional structure corresponding to a passive predicate (not in Tukang Besi, but generally) would be similar to that shown in (53) (assuming, for the sake of simplicity, an English-like phrase structure). Although a passive necessarily involves a reassignment of grammatical functions, unlike the case for pronominal agreement marking in Chichewa, the commonality with pronominal agreement systems is that the pragmatic function of topicality is assigned to the $P$ argument based on the morphological choice on the verb.

(53) Generic language: Agreement for $\mathrm{P}$ subject, passive voice: $\mathrm{P}$ topical, $\mathrm{A}$ core
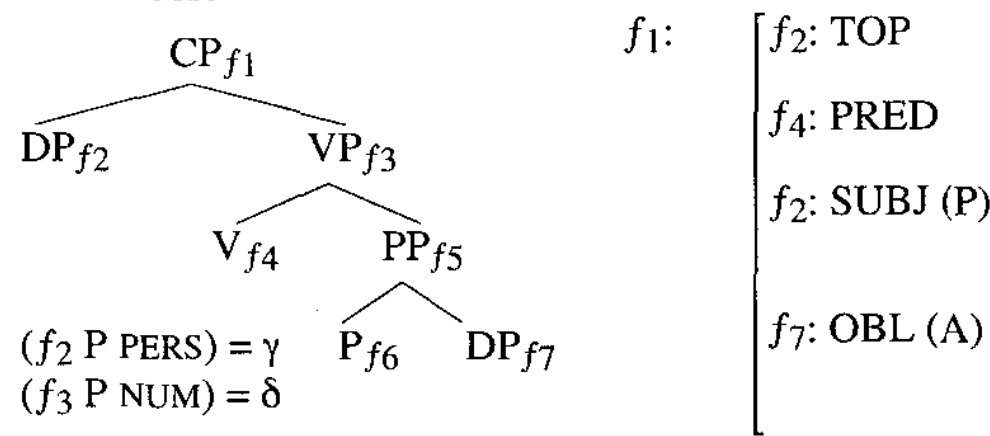

$$
\left.\begin{array}{l}
{\left[\mathrm{PRED}={ }^{\prime} . .\right.} \\
\langle\mathrm{SUBJ}\rangle,\langle\mathrm{OBL}\rangle \\
{\left[\begin{array}{l}
\mathrm{PERS}= \\
\mathrm{NUM}=
\end{array}\right]} \\
{\left[\begin{array}{l}
\mathrm{PRED}= \\
\mathrm{PERS}= \\
\mathrm{NUM}= \\
\mathrm{NU}
\end{array}\right]}
\end{array}\right]
$$

It is not hard to see how an agreement system with an optional pronominal element, associated with some level of increased pragmatic force, can develop into a voice system with grammatical as well as pragmatic status associated with its alternations. The pronominal voice system in Tukang Besi 
involves an alternation between a structure such as (54), representing the clause without P-enclitics, and (55).

(54) Tukang Besi: Agreement for A only: A \& P core

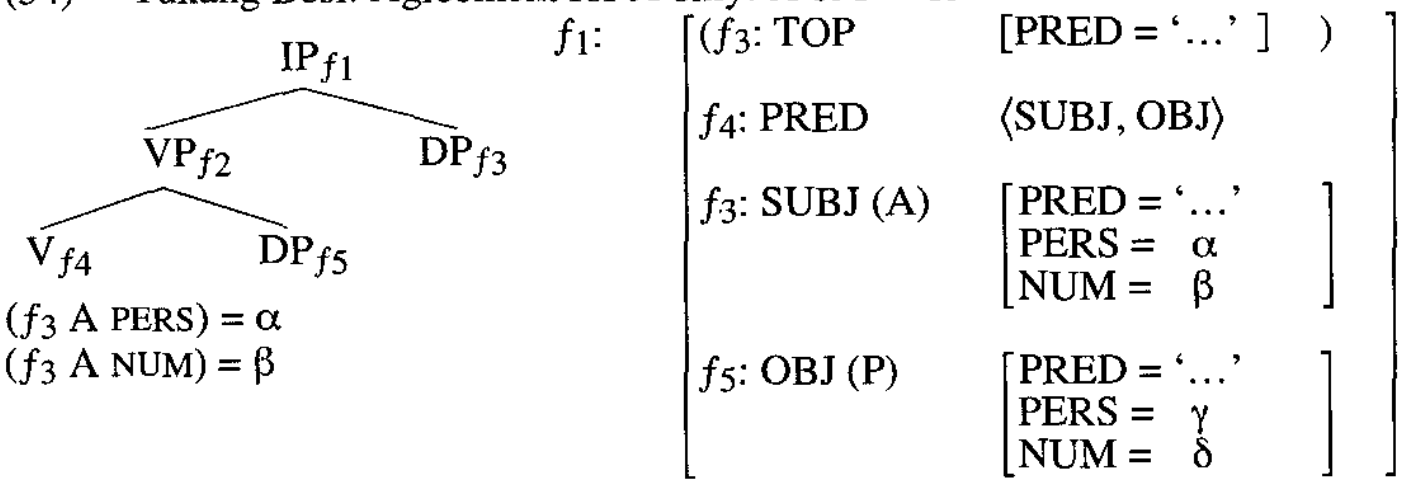

OBJ SUBJ

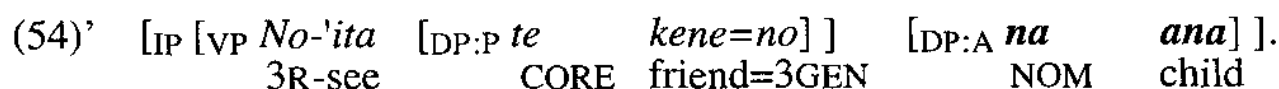

'The child saw her/his friend.'

(55) Tukang Besi: Agreement for A and P: P more topical, A core

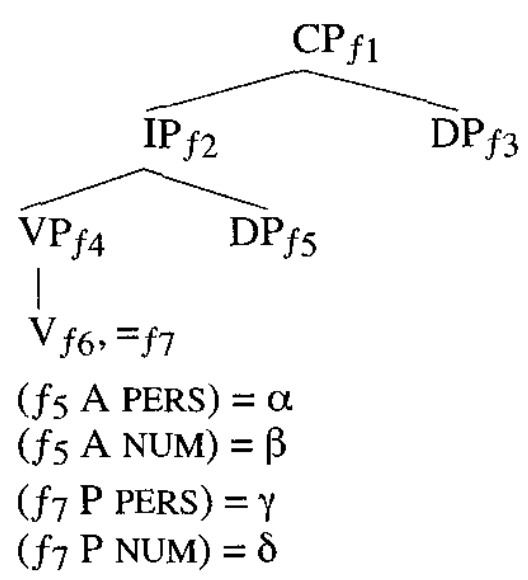

$f_{1}: \quad\left[f_{3}:\right.$ 'TOP' $=f_{7} \quad\left[\mathrm{PRED}={ }^{\prime} \ldots{ }^{\prime}\right]$

$f_{6}:$ PRED $\quad\langle$ SUBJ, OBJ $\rangle$

$f_{7}: \operatorname{SUBJ}(\mathrm{P}) \quad\left[\begin{array}{l}\mathrm{PRED}= \\ \mathrm{PERS}=\alpha \\ \mathrm{NUM}=\delta\end{array}\right]$

$f_{5}: \mathrm{OBJ}(\mathrm{A})$

$\left[\begin{array}{l}\text { PRED }=‘ \ldots \\ \text { PERS }=\alpha \\ \text { NUM }=\beta\end{array}\right]$

$\left(f_{7}\right.$ P PERS $)=\gamma$

OBJ

SUBJ

(55)' [CP [IP [VP No-'ita='e] [DP:A te ana]] [DP:P na kene=no] ] ]. $3 R-s e e=3 P$ CORE child NOM friend=3GEN 'The child saw her/his friend.'

Some predicates can be used either monovalently or bivalently. When they are used bivalently they must appear with P-enclitics (Donohue 1999a: 100). This indicates a slight preference for the inverse voice in a bivalent clause. This suggests that the bivalent use is dependent on combination with a predicate, either a causative one that specifies only the linking of the predicates, or a pronominal voice derivation that not only specifies predicate linking but also the voice that assigns the grammatical function subject to the $P$. See Sells (2000) for a model that is even more plausibly instantiated in Tukang Besi than in the languages for which it was developed. 


\section{Other attestations of pronominal voice}

Similar evidence for pronominal voice systems similar to that described here can be found in other Austronesian languages to the east (Larike, Ansus and Ambai, Misima, Saliba, Tawala; Laidig and Laidig 1995, Callister 1987, Margetts 1999, Ezard 1997); the unrelated (but geographically contiguous) West Papuan languages of North Halmahera (eg., Wimbish 1991) (in an inverted form); Mixe (Oto-Manguean, Mexico; Dietermann 1998), Dullay (Cushitic, east Africa; Sasse 1984: 247) and Lango (xxxx, east Africa; Noonan 1992 and others).

Generally there is less reported morphosyntactic evidence for the pronominal voice system in these languages; in some cases this reflects the level of published documentation (eg., Muna; van den Berg 1989), in some cases it reflects genuine 'fuzzy' language phenomena, in which the level of grammaticisation is not complete, such as in Ansus; the most comparable construction is textual coreference: for a chain of subjects; new participants are introduced as objects, and then (if they stay) become subjects.

\section{Endnotes}

ACKNOWLEDGEMENTS: I would like to thank Cathryn Donohue, who first called this phenomenon a 'discourse passive', ten years ago. Participants at the AFLA conference in Berlin have, through their comments, added to this exposition.

1. There are exceptions to this trend of under-reportage; Arka (2000) reports on the behaviour of passives in several languages of eastern Indonesia, where the nominal marking (case and/or position) is overtly present and correlates with demonstrable syntactic behaviour, but there is no dedicated passive morphology on the verb. Palu'e (Donohue 2004) has a similar system.

2. Because of the Philippinist controversy over grammatical functions, I shall use the labels A, S and P (following Comrie 1978) to refer to the syntactic roles, without making claims for their grammatical status at this stage. A, S and $\mathrm{P}$ refer to the most agentive argument in a lexically bivalent clause, the single argument in a monovalent clause, and the non-A non-oblique argument(s) in a bi- or trivalent clause, respectively.

3. A further alternative is available in which one nominally appears preverbally (yet clause-internally), with pragmatic focus: this argument can only be the $\mathrm{P}$ in a clause with P-enclitics, or the A (or S) in a clause without P enclitics. Additionally, any DP may appear preverbally if it is topical. A preverbal argument is invariably marked with te.See 2.3 and 2.4 for examples.

4. The P clitics only show morphophonemic variation: the third person clitic is realised as $[\mathrm{kE}]$ following a syllable with a glottal stop onset. The variation in the third person prefixes, and in the $2 \mathrm{SG}$ realis prefixes, is unconditioned.

\section{References}

Alsina, Alex. 1996. The role of argument structure in grammar: evidence from Romance. CSLI publications, Stanford University. 
Arka, I Wayan. 2000. Voice and Being Core: evidence from (Eastern) Indonesian Languages. Paper presented at the AFLA 7 Conference Amsterdam, May 2000.

Arka, I Wayan, and Christopher D. Manning. 1998. Voice and grammatical relations in Indonesian: a new perspective. In Miriam Butt and Tracey King, eds., On-line LFG proceedings. Available at http://wwwcsli.stanford.edu/publications/LFG3/lfg98-toc.html.

Berg, René van den. 1989. A grammar of the Muna Language. KITLV, Verhandelingen 139. Dordrecht/Providence: Foris.

Bresnan, Joan, and Sam A. Mchombo. 1987. Topic, Pronoun, and Agreement in Chichewa. Language $63: 741-782$.

Callister, William. 1987 (for 1985). 'How Austronesian focus works in the Misima language. Language and Linguistics in Melanesia 16 (1-2): 7199.

Comrie, Bernard. 1978. Ergativity. In Winifred P. Lehmann, ed., Syntactic typology: studies in the phenomenology of language: 329-394. Sussex: The Harvester Press.

Dahlstrom, Amy Louise. 1991. Plains Cree morphosyntax. Outstanding dissertations in linguistics series, Jorge Hankamer, ed. New York: Garland Publishing.

Dieterman, Julia Irene. 1998. Participant reference in Isthmus Mixe narrative discourse. Journal of Translation and Textlinguistics 10: 47-79.

Donohue, Mark. 1999a. A grammar of Tukang Besi. Berlin: Mouton de Gruyter.

1999b. Syntactic roles vs. Semantic roles: External Possession in Tukang Besi. In Doris Payne and Immanuel Barshi, eds., External Possession. Typological Studies in Language No. 39: 373-401. Amsterdam: John Benjamins.

2002. Voice in Tukang Besi and the Austronesian voice system. In Fay Wouk and Malcolm Ross, eds., The history and typology of western Austronesian voice systems: 81-99. Canberra: Pacific Linguistics 518.

2004. The Palu'e passive: from pragmatic construction to grammatical device. In I Wayan Arka and Malcolm Ross, eds., Voice in Western Austronesian languages. Canberra: Pacific Linguistics.

Ezard, Bryan. 1997. A grammar of Tawala, an Austronesian language of the Milne Bay area, Papua New Guinea. Canberra: Pacific Linguistics C137.

Falk, Yehuda. 2000. Philippine subjects in a monostratal framework. In Carolyn Smallwood and Catherine Kitto, eds., The Proceedings of the Austronesian Formal Linguistics Association VI: 133-136. Toronto Working Papers in Linguistics. Also available at htto://pluto.mscc.huji.ac.il/ msyfalk/Philippinesubje cts.pdf.

Georgopoulos, Carol. 1985. Variables in Palauan Syntax. Natural Language and Linguistic Theory 3: 59-94.

1998. Direct object definiteness effects. Canadian Journal of Linguistics 43 (3/4): 307-340.

Givón, Talmy. 1976. Topic, Pronoun and Agreement. In Charles Li, ed., Subject and Topic: 149-188. New York: Academic Press.

Kissock, Madelyn J. 2003. Transitivity and Objecthood in Rotuman. Oceanic Linguistics 42 (1): 145-160. 
Laidig, Wyn D., and Carol J. Laidig. 1995. A synopsis of Larike phonology and syntax. In Wyn D. Laidig, ed., Descriptive studies in languages of Maluku Part II. NUSA: linguistic studies of Indonesian and other languages in Indonesia 38: 19-42. Jakarta: Universitas Katolik Indonesia Atma Jaya.

Margetts, Anna. 1999. Valence and transitivity in Saliba: an Oceanic language of Papua New Guinea. Ponsen \& Looijen BV.

Noonan, Michael. 1992. A grammar of Lango. Berlin: Mouton De Gruyter

Payne, Thomas. 1994. The pragmatics of voice in a Philippine language: Actor-focus and goal-focus in Cebuano narrative. In Talmy Givón, ed., Voice and inversion: 317-64. Amsterdam : John Benjamins.

Sasse, H.J. 1984. The pragmatics of noun incorporation in Eastern Cushitic languages. In Frans Plank, ed., Objects: towards a theory of grammatical relations: 243-268. London: Academic Press.

Sells, Peter. 2000. Raising and the order of clausal constituents in the Philippine languages. In Ileana Paul, Vivianne Phillips, and Lisa Travis, eds., Formal issues in Austronesian linguistics: 117-143. Dordrecht: Kluwer.

2001. Form and function in the typology of grammatical voice systems. In Géraldine Legendre, Jane Grimshaw and Sten Vikner, eds., Optimalitytheoretic syntax: 355-391. Cambridge: MIT Press.

Schachter, Paul. 1976. The Subject in Philippine languages: Topic, Actor, Actor-Topic, or None of the Above. In C.N. Li, ed., Subject and Topic: 491-518. New York: Academic Press.

1977. Reference-related and Role-related properties of Subjects. In Peter Cole and Jerrold M. Sadock, eds, Syntax and Semantics 8: Grammatical Relations: 279-305. New York: Academic Press.

Wimbish, Sandra Gay. 1991. An introduction to Pagu through the analysis of narrative discourse. MA thesis, University of Texas at Arlington.

Wouk, Fay, and Malcolm Ross, eds.2002. The history and typology of western Austronesian voice systems: 81-99. Canberra: Pacific Linguistics 518.

Mark Donohue

National University of Singapore

Department of English, Language, and Literature

National University of Singapore

Block AS5, 7 Arts Link

Singapore $\quad 117570$

mark@donohue.cc 